\title{
Women of Color in Academia and the Influence of Religious Culture on Self-Promotion: A Collaborative Autoethnography
}

\author{
Joni Schwartz ${ }^{1}$, Eman Mosharafa ${ }^{1} \&$ S. Lenise Wallace ${ }^{1}$ \\ ${ }^{1}$ City University of New York, La Guardia Community College, New York, USA \\ Correspondence: Joni Schwartz, City University of New York, La Guardia Community College Department of \\ Humanities-Communication Studies, 31-10, Thomson Ave. C745F Long Island City, NY, 11101, USA. Tel: \\ 1-516-816-2886. E-mail: jschwartz@lagcc.cuny.edu
}

Received: February 8, 2016

Accepted: March 13, 2016

Online Published: March 20, 2016

doi:10.5539/res.v8n2p85

URL: http://dx.doi.org/10.5539/res.v8n2p85

\begin{abstract}
Much has been written about self-promoting communication by women in business, and some about self-promotion and women in academia. However, few studies specifically focus on Women of Color in academia in regard to how their religious backgrounds impact learned self-promotion communication and acclimation to academic culture. This collaborative autoethnography addresses this gap in the literature. Through two of the authors' life experiences in the Black/African American church and Islamic faith, self-promotion is explored as it relates to their current work in academia.
\end{abstract}

Keywords: self-promotion, impression management, collaborative autoethnography, women of color, Black/African American church, Islamic religious culture, academic culture

\section{Introduction}

We have known for decades that effective self-promotion is a key to advancement and satisfaction in the workplace, but we have also understood that women may "pay a price" for promoting themselves, often risking appearing too aggressive and bold (Rudman, 1998). For men, self-promotion is normative, an acceptable and expected communication behavior in the American workplace (Miller, Cooke, Tsang, \& Morgan, 1992). Our hope is that this divergent view of the use of self-promotion, when utilized by women and men, may be changing, but current research is unclear. According to Shambaugh, it is not a glass ceiling that is holding women back, but it is their own self-perceptions, communication and self-promotion that are still the obstacle (2008).

According to the National Association of Female Executives (NAFE), "more than a third of Fortune 500 managers and more than half of those with multidisciplinary master's degrees are women. Yet women hold only about 2 percent of Fortune $500 \mathrm{CEO}$ positions and represent 8 percent of the top earners among executives" (MaryAnn, 2011). "Compared to each dollar a White man earns, White women earn 77 cents, African-American women earn 62 cents, and Latinas earn 53 cents" (MaryAnn, 2011). These disparities may be correlated, clearly not entirely, at least in part, to women's continued ineffective understanding and skill in self-promotion (Shambaugh, 2008; Liff \& Ward, 2001; Rudman, 1998).

According to an article in The Economist (2013), this same phenomenon of disparity may hold true in academia as it does in business with the author citing several reasons for the lower number of female professors in the higher levels of both STEM and the humanities. Besides taking time to raise children, and men promoting men, the article states that women in academia are not "pushy enough". Therefore, women do not rise to the higher echelons of academia or are not promoted as often. Examples of how women academicians do not cite their own work or seek acclaim for their accomplishments are presented - examples of self-promotion. Connelly and Ghodsee (2011) write frequently on the value of self-promotion and provide concrete strategies for junior faculty working toward tenure. Their advice is to self-promote without shame or guilt.

When it comes to Women of Color in the academy, self-promotion seems to become an even more complex issue stemming from what Gregory calls "herstorical"-background of racism and oppression which play out in the workplace. For Gregory, self-promotion should be tempered and Black female academicians should be careful to "toot their own horns" (p. 106). Johnson-Bailey and Cervero's comparison of a Black female professor and a White male professor's academic careers entitled "Different Worlds and Divergent Paths" is a fascinating 
introduction into the contrasting communication experiences and trajectories based on both race and gender. How to self-promote within these dynamics for Black female professors is one of the foci of this article.

To further "unpack" Women of Color and self-promotion, for the past twenty years there has been an increasing presence of international faculty in the American professoriate particularly in the STEM disciplines but throughout the entire university system (Kim, Twombly, \& Wolf-Wendell, 2012). This rapid change in the composition of the American professoriate has ramifications for female international faculty with divergent cultural and religious influences that may play upon women's views of self-promotion and the navigation of their academic careers.

It is within this context that this article presents a collaborative autoethnography focusing on two women of color in the American professoriate - one an international scholar of Egyptian descent and a Black female of Hispanic descent born and raised in the United States. The collaborative autoethnography examines the influence of religion, culture, and race on their concepts of self-promotion in academia and their resulting communication behaviors at the university generated by their background and beliefs.

\section{Defining Self-Promotion}

For purposes of this article, self-promotion will be defined as communication and impression management behavior (Jones \& Pittman, 1982) that seeks to increase and augment others' favorable perceptions of the self in a particular setting or context. Self-promotion includes identifying and pointing out one's own accomplishments and achievements, speaking straightforwardly about one's own talents and abilities, and taking personal credit for the attainment of such accomplishments, attained goals, talents and demonstrable skills (Rudman, 1998). Self-promotion is one of taxonomy of communication impression management strategies including: ingratiation, exemplification, intimidation, and supplication (Jones \& Pittman, 1982) that seek to control the impression one is giving to others about themselves. Self-promotion occurs when individuals draw attention to their accomplishments in order to give the impressions to observers that they are competent and capable (Rudman, 1998).

Impression management can be either conscious or unconscious (Piwinger \& Ebert, 2001; Goffman, 1959) and is related to self-presentation in both public relations and organizational communication (Kamau, 2009). Not as often associated with academia, impression management including self-promotion is key to navigating the culture of academia. Knowledge and understanding of the cultural capital of the academy and how Women of Color may bring new understanding of self-promotion based on their own cultural and religious backgrounds is the exploration of this article.

\section{Research Design and Method}

Autoethnography is a qualitative research method utilizing data about the self and self-narrative often centering on an experience that is life-changing; autoethnography is commonly employed in communication studies research. Types of autoethnographic designs range from evocative approaches, centering on performance and solely self-narrative, to analytic designs that combine the self-narrative with more traditional research methods (Ngunjiri, Hernandez, \& Chang, 2010). This study employs an analytic autoethnographic design (Anderson, 2006).

Data sources are the three collaborating authors utilizing the data collection methods of their own reflective processes through journaling, intergroup dialogue, and informal interview survey questions. All are junior faculty in a large urban East Coast university system. All are tenure track professionals in the humanities. One author identifies as a Black/Hispanic female Christian; a second, an Egyptian/Muslim female, and lastly, a White American of Czech descent, Christian. The third author serves as a participant observer in the tradition of ethnography while the two lead authors, who are Women of Color, are actively involved in the autoethnographic process. As a collaborative autoethnography, there searchers are both insiders and outsiders in the ethnographic context.

Data was collected through author focus groups, self-surveys and journaling, which became evolving drafts. The surveys and drafting involved a self-reflective process with ongoing conversation between authors. All written data was compiled in NVivo, a qualitative data analysis software program. Beyond the authors' self-reflective analysis, a grounded theory approach utilizing context analysis through initial opening coding, axial coding and word frequency analysis (Strauss \& Corbin, 1998) using NVivo was used for supplemental and secondary analysis.

\section{From a Muslim Eye-Self-Promotion}

As a woman growing up in Cairo, the Islamic values instilled in me during my childhood, primarily as a model of good behavior, consistently act as guide posts to this day, whether I follow them or not. Most generally I follow the guideposts, and when I stray, I never stray too far. Growing up my parents expected that I excel in studies to pursue 
big dreams, and that, as a woman, I was capable of doing anything as long as I put my mind to it. I was encouraged to travel to new places. I was encouraged to play music and participate in sports. I was really encouraged to develop and grow skills and talents that God has bestowed on me. I was never told that Islam in any way discouraged this, but my family's understanding is that my faith encouraged it and that I would be a good, productive Muslim as a result. Islam has not forced me to think of myself in terms of gender, but instead, as a human being trying to use his or her gifts to make this world a better place for humanity during my lifetime.

I must admit that my family's understanding of Islam was very progressive in comparison with Egyptian norms. Despite how much my parents tried, many sexist ideas among Egyptian society still permeated through. In the following section, I will discuss how the concept of self-promotion is perceived in Islamic culture in connection with gender socialization. Through personal life and work experiences, I will demonstrate how the discrepancy in self-promotion between Islamic and American values may put Muslim minorities at a disadvantage in academia especially for women.

\subsection{Self-Promotion in Islamic Doctrine}

"And do not turn your cheek [in contempt] toward people and do not walk through the earth exultantly. Indeed, Allah does not like everyone self-deluded and boastful," (Quran 31:18). Modesty is humbleness in speech, behavior, attitude, and dress. It is shyness, simplicity and humility about our abilities and accomplishments. Whether it is wealth, beauty, intelligence, strength, or any other appealing trait, one is not to brag about them. These privileges are bestowed upon a person by God and can be retaken if it is God's will. A person who self-promotes is one who gives credit to him or herself, which goes against this concept. Hence, self-promotion is considered improper. A common saying in Egyptian society is the phrase: I take refuge in God from the word "I" (أعوذ بالله من كلمة أنا), which shows how dreadful society considers talking about oneself. In an Islamic culture, self-promotion would be considered an act of showiness and arrogance.

One of my Egyptian friends was on a hiring committee in an Egyptian/American institution, encountering for the first time American applications. Upon reading the first application, he was shocked to find the applicant's claim to be the most eligible for the job. The Egyptian committee member judged the applicant as arrogant and decided to exclude him from the search. To his surprise, all other American applications shared the same pattern.

Both American and Islamic cultures advocate choosing the best fit for the job, but differ in their evaluation of the candidate's attitude. American culture appreciates self-promoting. A person who asserts him or herself is seen as confident, self-motivated, and firm. In contrast, Islamic culture rejects such a behavior and condemns self-promotion for the following three reasons.

\subsubsection{Objectivity}

Islamic culture does not regard self-praise as credible because it is not objective. Anyone can claim to be the best. This claim has value only when stated by others. Hence, Islamic culture endorses peer nomination as an alternative to self-promotion. This reasoning is consistent with research that shows that a person's perception of oneself is distorted by one's own personal interests. The term "self-serving bias" refers to the tendency of people to judge themselves generously. People are inclined to credit their successes to personal attributes and to blame their failures on external factors. Conversely, when people evaluate others, they are inclined to judge them more harshly or perhaps more honestly (Manusov \& Spitzber, 2008).

\subsubsection{Fear of Self-Indulgence}

Especially with leadership positions, it is feared that a person desires a position of authority for personal rather than public interests. Hence, in Islamic culture, those who actively seek high status positions are not well regarded. An exception is in times of crisis. A person who has the expertise to help is allowed to request a specific position to provide assistance. But generally speaking, those who request a position are to be denied. Prophet Muhammad (S) is reported (by Abu Musa) to have said: "We do not appoint to this position one who asks for it nor anyone who is covetous for the same," (Sahih, 1733). Also, according to Bin, the prophet told him:

Abd al-Rahman, do not ask for a position of authority, for if you are granted this position as a result of your asking for it, you will be left alone (without God's help to discharge the responsibilities attendant thereon), and if you are granted it without making any request for it, you will be helped (by God in the discharge of your duties) (Sahih, 1652).

In politics, while it is acceptable in the West to campaign for a post, in Islamic culture campaigning for a position of power may be perceived as self-indulgent. Hence Islamic culture has historically used a number of approaches in which the nomination is made by peers and not by oneself. For instance, when the prophet died, his successors, the first four Caliphs of Islam referred to as the rightly-guided caliphs, were chosen by these methods (Afsaruddin, 
2013):

Abu Bakr Al-Siddik became Caliph after the community selected him to succeed the prophet and offered him pledge of allegiance. Umar Ibn Al-Khattab became Caliph after he was appointed by his dying predecessor Abu Bakr. The community accepted the appointment and offered him pledge of allegiance. UthmanIbnAffan became Caliph after he was nominated by an electoral council appointed by his dying predecessor Umar.

Ali IbnAbiTalib became Caliph after the majority of Madina residents offered him pledge of allegiance. However, violence erupted soon after as his nomination was opposed by two prominent Companions Talha and al-Zubayr, and the Prophet's youngest widow Aesha. As these examples show, none of the caliphs had requested to rule, instead they were nominated and promoted by others.

\subsubsection{Serving God}

A devout Muslim carries out good deeds in order to serve God. The incentive for doing good is not to be rewarded on earth but to please God (ابتخاء لوجه الها). Whether it is working with dedication, offering donations or acting honorably, one's reward is not a bonus or promotion. The real prize is to obtain closeness with God. Many verses assert this meaning:

"[He] who gives [from] his wealth to purify himself. And not [giving] for anyone who has [done him] a favor to be rewarded. But only seeking the countenance of his Lord, Most High. And he is going to be satisfied" (Quran 92:18-21).

And the verse: "And as for those who believe and do good works, he will pay them their wages in full. Allah loves not wrong-doers" (Quran 3:57). Also Abu Hurayrah reported that Prophet Muhammad (S) has said: "He who acquires knowledge not to serve God but only to get some worldly advantage will not reach the scent of Paradise" (SunanAbiDawud, p. 3664).

Hence, if one genuinely pursues God's approval and nothing else, it is meaningless to cite one's good deeds to fellow men. In addition to being arrogant, a Muslim who is marketing him or herself is one who seeks praise from people and not from God. My cousin has created a website that educates people about Islam; her name is not identified anywhere on the website. This example illustrates how we are taught not to seek recognition or credit for our good deeds.

\subsection{Gender Socialization and Women's Employment}

Muslim countries vary on their records for women's rights. Depending on various readings from the Quran and Hadith, Muslim countries implement different laws all in the name of Islamic Sharia. Egypt is considered to be a moderate Islamic country with progressive laws which protect women's rights to be educated, work, and obtain leadership positions. However, local culture still holds traditional gender roles, which consider the prime responsibility of woman is to take care of the home and children. According to research in domestic work by gender, results showed that among the 357 sampled adolescents aged 16-19 who were attending school, 68 percent of girls versus 26 percent of boys reported doing domestic work the previous day (Mensch, Ibrahim, Lee, \& El-Gibaly, 2003). The continued endorsement of stereotypical gender roles has career and social consequences for women.

\subsubsection{Choosing a Career}

Since first grade we were taught that the prophet Mohamed said: "Heaven is under the foot of mothers." The quote says "mothers" not "working women." In regard to career consequences, the view that professional work for women is secondary affects career choices. According to the World Bank's book (2014), as recent as 2012, the percentage of working females in Egypt is only 24.2\%. Women are not expected to provide for themselves; hence a topnotch job with a high salary should not be a target for a female. The priority when choosing a job is to look for one that accommodates her primary role as a wife and a mother and to avoid the ones which require a high number of working hours. Girls are socialized to believe building a career is not a priority for women nor is working towards self-actualization and accomplishing high achievements.

This is actually the reason why I chose to become a professor. Professors have flexible schedules and academia is less demanding of time than the private sector. I loved working in the media field. For a couple of years, I worked as an assistant producer, a reporter, and an account executive in an advertising agency. However, I switched to academia as it is more suitable to my future role as a wife and a mother. It wasn't until I went through the devastating experience of a divorce that I started to challenge this aspect of my culture. I now realize that it is a necessary for women not only to have a career but also to thrive in it to become independent and be treated on the same level as men. 


\subsubsection{Speaking in Low Voice}

Women are socialized to speak softly and in a low voice. They are taught not to confront but to smooth-over situations. Now, as an established career woman, I feel strongly against a woman taking a back seat, whether voluntarily or involuntarily. But, while I mentally recognize that I should be more outspoken, it is hard to reverse years of socialization. In various department and committee meetings, I have to push myself to voice my opinions, especially disagreements.

\subsubsection{Discarding Leadership}

Society propagates that men should lead and women are to be submissive to men. For example, when praying, only males can lead the prayers. Women may lead the prayers only in the absence of a male. When examining patriarchal views of gender relations between husband and wife, the majority of the sampled 288 female adolescents agree that a wife "needs her husband's permission for everything" (87.5\%) and that a wife must accept a husband's opinion if she differs with him (56.4\%) (Mensch et al., 2003).

Girls are taught not to be assertive, but to depend on men. For instance, if bullied, a girl, instead of standing up for herself, is taught to seek protection from her brother. Moreover, a girl with high intelligence and skill is commonly taught to fake incompetence in a male presence to protect his ego and status as the leader. In third grade, my teachers held elections for class president and vice president. I was very popular and could have won class president. But, because of a mental image that the ideal setting is for the president to be male, I refrained from nominating myself for the position and instead ran for vice president. I won unanimously. This story illustrates how I learned at a very young age to suppress my ambitions and to relinquish leadership roles. This mindset goes completely against the notion of self-promoting and marketing.

\subsubsection{Self-Promotion or Lack Thereof}

Growing in a culture that despises self-praise and encourages women to keep a low profile, I hardly do any self-promotion. I do not talk much about my work or accomplishments and this has gotten me into trouble at least once that I am aware of. I co-chaired with a male colleague on a Communication Studies Open House organizing committee. Being the modest person I am, I never spoke of the challenges I faced or the time my duties consumed. My partner developed the impression that my contribution was minimal and told the program director that he didn't need my help. I kept silent. The following year, my partner took on my duties. The Open House did not go as well as he anticipated. My former partner later came and apologized for underestimating my contribution, accrediting my role in the success of the previous year.

Another example is when one of my co-authors pointed out that I don't talk about my accomplishments. She advised me that when I publish I should alert my colleagues and think about how to publicize the research I do. After these two incidents, I have been more proactive. I now outline the achievements and projects that I've completed, albeit I don't add adjectives to qualify the work. Praise for my work continues to come from my colleagues who have worked with me, and that has served me well. For example, a colleague with whom I co-led a workshop on challenges in higher education has nominated me to serve on the steering committee for a project titled "Unthinking Muslim Identity. Another member of this steering committee nominated me to serve on a hiring committee, and several colleagues who read a paper I wrote on social media have asked me to work with them on different college-wide projects. Despite my different ingrained cultural values around self-promotion, working in academia has been a positive experience. I believe my colleagues see me as a person who happens to be Muslim - they see me as me, not as my faith. As long as I turn in good work and I treat everyone with respect, they in turn respect me back.

Perhaps the academic environment is somewhat more accepting of differences than corporate America. Muslim friends who don't drink and those who observe Ramadan find some challenges in the corporate setting. Wining and dining are important parts of business when it comes to connecting with clients; refraining from drinking hinders this aspect of business. In addition, observing Ramadan means refraining from eating, drinking, or smoking until sunset. Deprived from coffee or even a glass of water, Muslim employees struggle to keep their high performance. They feel under tremendous pressure, for fasting cannot be an excuse for being less energetic.

In summary, Islamic culture is one that promotes communal rather than individualistic values. One is encouraged to take on their work duties and help others without looking for credit. Islamic culture assumes that one's work will show itself; hence no need to publicize one's accomplishments. However, in the real world, management is busy; employees need to speak up for themselves and cite their successes otherwise their work might go unnoticed. Perhaps Muslim/Arab minorities living in the U.S. are at a disadvantage in the workplace; they are not trained to self-promote as they are raised with a value system that despises such behavior. With women, the situation is 
worse as they are taught to keep a low profile. However, from my perspective I think working in academia might be better than the corporate world since academic institutions are likely to be more tolerant of cultural differences.

\section{Self-Promotion in Academia: From the Lens of a Black Latina}

The concept of "self-promotion" in academia was non-existent for me, particularly because I did not know it was needed. By no means do I infer that now that I have a doctorate and a faculty position at a college that I feel I have "arrived"-I just believed that all I did would truly speak for itself - committee and departmental work, faculty mentorship, publishing, etc. I listed these contributions on my yearly evaluation forms and discussed them with my chair. It never crossed my mind that self-promotion, outside of the once-a-year meeting with my chairperson, would actually matter. The majority of my professional work experience was in corporate America in the Public Relations world - not only do I know a bit about promotion, but I totally understand the concept of self-promotion - in corporate America.

I remember in corporate America, people self-promoted themselves quite often. In weekly meetings, colleagues frequently alerted our chairperson about specific ideas they had conceived and media placements they had secured. Frequently, these weekly brainstorming meetings would turn into very competitive, sometimes combative, meetings with people touting their own accomplishments. One of those meetings actually turned into a physical altercation; fortunately, I was not present for that one.

This "gloating", often from my male colleagues, was a turn off to me. I thought of this as being prideful, braggadocios, and not humble, also bragging. For me, as an introvert, I am just not one to draw attention to myself. Not to mention, I had enough public relations agency experience to know that as a Woman of Color, sometimes ideas of mine were overlooked, totally dismissed or even worse-I was invisible. Once, with a very high-profile music company client for whom I was the lead account person (and in constant communication), I felt a sense of accomplishment that the client was satisfied with my work and ideas. However, I felt completely blindsided when my younger White assistant was chosen over me (by my CEO) to meet the client in person when he came in from California. Unfortunately, I have several stories like that one, as a woman of color - in corporate America, self-promotion for me was either pointless or had little value. I had witnessed nepotism in its highest form in a couple of the agencies I worked for and sometimes people were just not as ethical as I thought they should be. It wasn't until I worked at a Multicultural Public Relations Agency, that I truly felt valued. The CEO for the Multicultural agency was African-American. The organization, however, was very multicultural and race/gender matters were never an issue here.

Lastly, within the process of this research project and personally witnessing people in my current academic organization self-promote, I can see the benefits of positive self-promotion. This research has caused me to reflect and view the concept of self-promotion from another perspective. I no longer see self-promotion as negative - within the right context. I have personally witnessed current colleagues positively and professionally self-promote their excellent work in a way that highlights their accomplishments - but not only to promote themselves, but also to highlight our students and promote the collaborative work with them. Presently, at my current academic institution, I feel the same as I did while at the Multicultural firm - valued and supported.

Consequently, inspired by the latter part of this present research, I have started to self-promote. I am an advisor and mentor for a group within my institution and under my mentorship and leadership several opportunities have arisen. Normally, I would have kept these great opportunities to myself. However, on two occasions since exploring this autoethnography, I sent emails to my chairperson alerting him of these happenings under my leadership and involvement. Even though minor to some people, that is a step for me and I look forward to humbly and positively self-promoting within my organization in the future. It is crucial to investigate the origins of why many women of African descent frown upon self-promotion and how the Black/African American church maybe a contributing element to that reasoning.

\subsection{Black Women, the Black Church and Self Promotion}

It is well known that the Black/African American church has been the cornerstone of many Black/African American communities since slavery. Many Blacks/African Americans turn to their places of worship, not only to seek spiritual guidance and growth, but to be assets to their communities; learn about social justice; individual prosperity and fellowship with their brethren (Day, 2012). Traditionally, the Black/African American church leadership operates from an androcentric or male dominant view. However, seventy percent of Black churches are majority populated by women (Collins, 2004). The women in most churches do not hold management positions i.e. Pastors, First Elders, conference leaders etc. because it is often frowned upon for women to hold positions of leadership. Grant (1982) stated that, "In many churches women are consistently given responsibilities in the kitchen, while men are elected or appointed to the important boards and leadership positions. While decisions and 
policies may be discussed in the kitchen, they are certainly not made there" (p. 141). In many cases, some religious institutions cite the Bible as reference as to why men should lead the church. According to 1 Timothy 2:11-12, "A woman should learn quietness and full submission. I do not permit a woman to teach or to assume authority over a man; rather, she must be quiet" (New International Version). Despite this Biblical citation, there's a growing number of female pastors and clergy within the Black/African American church - a very controversial issue.

To reference the latter part of 1 Timothy 2:12 once again, there is an interesting phrase, "she must be quiet." It can be inferred that many Black/African American women take these words to heart and adhere to a submissive and silent role. Often this perspective transcends to other aspects of their lives, such as being subservient to the patriarchal structures of other institutions such as their places of employment and academic institutions. Silencing the Black woman within or outside the church is not a new concept. However, it is important that Black women and men understand that becoming empowered and establishing a "voice" is something that both groups must work on as a unit, not separately or this could be detrimental to the Black community. In her book, Black Sexual Politics: African Americans, Gender and the New Racism, Patricia Hill Collins stated that, "Black women can never become fully empowered in a context that harms Black men, and Black men can never become fully empowered in a society in which Black women cannot fully flourish as human beings" (p. 7). Although, many in the Black/African American church may not see the past and current patriarchal structures as harmful, I believe they have been, and a strong surge to promote Black women within the church to become empowered is essential.

\subsection{Born to Immigrants and Attending a Traditional Black Church}

As a female product of Black Latino immigrants from Costa Rica, I was born here in the United States. I was Christened, baptized and currently attend a historical landmark Black/African American/Caribbean church in New York City. In my personal observation, while growing up I have witnessed many women who did adhere to being voiceless. Many times I witnessed women deferring to the men of our church to have the last word. This is not necessarily a negative position, as many women believe in another component of the Bible, which states the man should be the head of the household. As Ephesians 5:22-24 states, Wives, submit yourselves to your own husbands as you do to the Lord. For the husband is the head of the wife as Christ is the head of the church, his body, of which he is the Savior. Now as the church submits to Christ, so also wives should submit to their husbands in everything (New International Version of Bible-NIV).

However, depending on how this is perceived, some could view this as being sexist and not a level playing field.

In our denomination, our pastors are moved from our churches and rotate every five to seven years, on average. In over thirty years, I have witnessed many pastors come and go. Never a female Pastor, nor female First Elder, however. In the Northeastern (United States) region of my denomination, out of 177 churches there are less than five female Pastors. According to Grant (1982) "The oppression of women in ministry took many forms. In addition to them not being granted ordination, the authenticity of 'the call' of women was frequently being put to test" (p. 143). In reflecting and observing my own immigrant family and friends, there often appears a need to remain "silent" and not "rock the boat" when being marginalized or mistreated in church or at the workplace. Although, I witnessed my parents having to stand up and defend themselves during extreme circumstances-I noticed that more often a passive approach was taken; perhaps because of fear of retaliation and/or punishment for being outspoken. In addition, many immigrants silence themselves due to the perspective that if they were to speak up and denounce being mistreated, they would seem ungrateful for any opportunity in the United States. Not wanting to appear arrogant and ungrateful, Black immigrants may not consider self-promotion in any circumstance. Establishing a voice may be risky.

There are also some economic and social penalties for some women who self-promote. Moss-Racusin and Rudman (2010) state, "The double standard for self-promotion is a critical barrier to women's equitable treatment because self-promotion is necessary for career advancement, yet only women risk penalties for it" (p. 187).

According to Grant (1982), "The status of Black women in the community parallels that of Black women in the church" (p. 145). It may be inferred that the woman's subservience in the church may be a reason why many Black/African American women do not self-promote in their places of employment or any entities outside of the church. This perspective coupled with the Black immigrant's not subscribing to the notion of self-promotion because of fear of negative retaliation or the perception of being boastful and ungrateful, may account for the Black immigrant woman's reluctance to engage in self-promoting behavior.

\subsection{Pride, Humility and Double Consciousness}

Another element that may hinder both Black/African American women and Black immigrant women from self-promotion is pride. Once again, referring to the Bible, there are several scriptures that discuss how being 
prideful is a negative characteristic. According to Proverbs 11:2, "When pride comes, then comes disgrace, but with humility comes wisdom" (NIV). In addition, in the NIV James 4:6 states, "...God opposes the proud, but shows favor to the humble" (NIV). According to the Merriam-Webster dictionary, pride can be defined as "a feeling that you are more important or better than other people." Although pride and self-promotion are different, for some people, the lines may be blurred. In an academic institution, according to Nevin (1991), it is imperative that there is a clear difference between pride and self-promotion. After attending an Association of Behavioral Science conference and participating in discussions, Professor John Nevin and his colleague Professor Neuringer went back to their respective institutions and discussed pride and humility with colleagues. According to Nevin (1991), the conclusion of these discussions was that, "A prideful behavioral stance could turn them away and keep us isolated, so a degree of humility is an inevitable part of collegiality." In addition, Neuringer argued, "humility is functional because it entails tentativeness, openness to criticism, and support for diversity" (p. 35).

Not unlike these scholars, some Black/African American women and Black immigrants view self-promotion as being prideful and not humble. Again, reverting to taking a silent submissive role - even if they believe they are worthy of promoting themselves, they may not. I believe there is theoretical framework that could explain the silent submissive role that many may take. Many Black/African American and Black immigrant women and men may experience what W. E. B. DuBois defined in The Souls of Black Folk as "double consciousness." The concept of double consciousness Dubois (1903) described is:

A sense of always looking at one's self through the eyes of others, of measuring one's soul by the tape of a world that looks on in amused contempt and pity. One ever feels his two-ness, an American, a Negro; two souls, two thoughts, two unreconciled strivings; two warring ideals in one dark body, whose dogged strength alone keeps it from being torn asunder" (p. 12).

DuBois' theory included a "veil" that African Americans figuratively are forced to wear and view life through the lens of race - theirs and their White counterparts. Through this "veil," the African American can visibly see inequalities and disparities in several areas between themselves and their White counterparts. DuBois explicated that trying to establish an identity in America as being an American and being African American while, at the same time, viewing the world through this "veil," can be challenging. According to Burke (2008):

For Black Americans, the veil stands between them and White America, inhibiting access to the privileges reserved for White Americans. This veil, in turn, prevents a true ability to see the problems of race for many White Americans. Although Black Americans are gifted by this second sight, which allows for a first-hand understanding of the problems of U.S. racism as well as the ability to operate in both a White and a Black world, White Americans' sight is limited. White Americans do not generally have the desire or the impetus to navigate Black America, and as such do not develop this dual awareness that has been central to the Black experience in the United States (p. 412).

One can infer that this theory could be the reason as to why some Black/African American women do not self-promote, particularly among their White colleagues. Unfortunately, viewing life through this "veil" maybe a deterrent to them regarding self-promotion making them reluctant to speak up, come to voice and confront when necessary. For some, in certain environments, double consciousness as DuBois once stated could be a blessing and a curse: a blessing because one is aware and has the discernment to these issues; a curse because of the reality and marginalization this can bring the African American.

From an autoethnographic perspective, my personal experiences are just that, one view of self-promotion which I have tried to frame within a larger context of the church and the immigrant experience. My own reflections may or may not be generalizable to all Black/African American women and Black immigrants through all generations who have relied on the church as the cornerstone of their communities. This makes them no less qualitatively valid.

\subsection{Personal Reflections}

Joining the professoriate was never my goal as a young child. I actually don't know many people that grow up stating that they want to be a college professor. More often the dreams are of being a doctor or lawyer. In my case, the sight of my own blood killed me softly, so any thought of choosing a career near the medical field was on the cutting room floor. I chose lawyer. As far back as grade school, I remembered wearing an oversized grey and white hound's tooth business suit to class. With my scribbled writing on file cards, I stood in front of my class stating that I wanted to be a lawyer and carry a briefcase every day. In high school, I was successful in my You and the Law classes as we would have "mock trials" and I would pose as the defense lawyer. Watching shows like "LA Law", "Perry Mason" and "Matlock" were some of my favorite pastimes in high school. So, naturally I majored in Political Science in college. I excelled in my major and had two internships. 
But around my junior year in college- - I started to change my mind. The one goal that I had earnestly set for myself began to lose interest for me. I finished my Bachelors in Political Science but had zero intention of going into law. Telling my immigrant parents of my decision was difficult because, in an immigrant household, actually becoming a lawyer or doctor was "making it". After telling my parents, I could sense their disappointment, but they trusted my decision. In addition, they had always encouraged me that I could do anything to which I put my mind. So, what next? I learned about the field of Public Relations on a whim and was interested in learning more. After some research, I was able to land an entry-level job at one of the top Public Relations firms in New York City - and the country. I had never been literally hired on the spot before. One interview with HR, and I was to start in two days. I was so excited to start this new chapter in my life.

The field of Public Relations (PR) was another world for me; I had never even considered communication as a major in college or truly knew what PR was. However, I learned from the ground up at this firm which represented real estate conglomerates, major New York sports teams, and celebrities. Every day was different, and my long hours and exposure made me want to learn even more. A local college had recently launched a master's degree program in public relations and corporate communication - the only PR program at the time in the metropolitan NYC area. I called the chair, met with him and subsequently started the program two weeks later. I remember my supervisor, who was Italian telling me, "you don't have to get your master's degree, just be like me, work for a few years at a firm - then every place you go get a 10k pay raise." She was 29 and at the time earning $\$ 125 \mathrm{k}$. I knew that she meant well with her advice, but as a woman of color, I knew something she probably didn't. I had to work twice as hard and earn those degrees to get even the same amount of consideration as my white counterparts.

Then I noticed the few people of color in managerial positions. There were three- one female who was a Vice President, one male who was a high level executive in the accounting department and another male who was the head of the mail room. Three high level executives of color in a company of over 160 people. This was my first job out of college, not to mention I was embarking on a new career, so I was thankful — despite the lack of diversity. I thought to try and be cordial with the one Black Vice President, but it seemed that she wasn't really interested. During my master's program I reached out to her for an interview and she complied. I was excited and she was helpful so I was optimistic that our relationship could grow into one of a mentor/mentee. That never happened. I didn't take offense. I just figured there was an age difference, and perhaps she just wasn't interested in taking me on as a "new project".

After successfully completing my master's degree, another unimagined inspiration emerged from this program - the goal of becoming a college professor. I went to the same chairperson who admitted me into the program, told him of my interest in teaching an Introduction to Public Relations class and for the second time, on the spot, I was hired. Thinking back, this may have been the first time I self-promoted professionally. Thus, my journey into the professoriate began. Once a week, every Tuesday - I jetted from my full-time PR job in NYC to this college in Westchester, NY to impart my knowledge of the field to my students. At 26, I looked so young that I was often mistaken for a student. Professionally, I was at an all-time high, and I knew there was no turning back.

It didn't take long to realize that I needed to earn my $\mathrm{PhD}$ in communication. I sought counsel from professors and the common advice was "yes" get the PhD. In May 2008, I obtained my PhD in Mass Communication and Media Studies. I am thankful to say that all five of my sisters have earned college degrees with some of those being graduate degrees. Not so bad for immigrant parents who entered this country with only a dream.

\section{Discussion}

As mentioned previously, to succeed and thrive in American academic culture impression management, including self-promotion are key. Based on the autoethnographic work of this article's authors both Muslim and Christian doctrine, the immigrant experience, religious cultures and expectations seem to inform these women's cognitive schemata as well as their communicative behavior choices in the professoriate. Specifically, in the areas of perceptions of women in regard to leadership, remaining quiet, pride or self-indulgent communication, allowing others to promote you (but not yourself), and collective vs. individualistic communication, both the teachings and interpretations of Scriptures in both religions are uncannily parallel.

Leadership in both ethnographic accounts is primarily reserved for men, is patriarchal in structure and continues to be slow to change. The very interpretations of the excerpts from the Holy Books, Quran and the Bible cited and presented by the authors purport a frame of reference that seems to encourage and continue to tenaciously support male dominance in religious leadership. Whether this is truly an accurate interpretation of these Scriptures is certainly arguable but, for purposes of this article, it is the interpretation absorbed by these professors. In regard to the silencing of women, this is in stark contrast to academia where silence is not all together valued. In fact, the ability to frame an argument, voice it, participate fully in debate and dialogue are often necessary for success in 
academic circles. The issue of pride or self-indulgence is another taught perception that if carried into academia potentially does not serve a young professor well. Academic culture rewards tactful self-promotion that appears neither prideful nor arrogant but nevertheless highlights the accomplishment of academicians in the forms of publication, grant writing, research, college contributions, and teaching in a collegial spirit. Strategic and intentional pursuit of tenure and promotion through the marketing of oneself is rewarded and expected. If this is interpreted as pride or arrogance, junior faculty — in this case, Women of Color - will not engage in the necessary self-marketing, but will wait for others to acknowledge and laud their accomplishments when often academic culture demands that they do so themselves.

The final parallel theme weaving through both autoethnographic sketches is collective versus individualistic cultures. American academic culture is primarily individualistic with demands for each faculty to produce a body of work in their field, gain individual recognition within that field, and move up the tenure track primarily alone. In contrast, Muslim, Middle Eastern, Black church and community cultures are primarily collectivist and use gendered communication. As demonstrated here, women of Color struggle to communicate in ways that promote themselves rather than the group well-being. This article suggests that these types of communication contradictions inhibit junior faculty of color, specifically women, in engaging in the types of self-aggrandizing communication valued in academia.

Our preliminary work here suggests that discussion around the kinds of cultural capital valued by American academia and how that is understood by international faculty as well as American faculty of color would be of support to junior faculty. How does one embrace one's own religious convictions, whether Muslim or Christian, as well as our own cultural upbringing and make sense of them within academia? Another question for exploration is how might academia change to embrace more collectivist values and communication behaviors that both international, and faculty of color bring to academia? These are conversations worth having.

\section{References}

Afsaruddin, A. (2013). The First Muslims: History and Memory. One World Publications, Kindle Edition.

Anderson, L. (2006). Analytic autoethnography. Journal of Contemporary Ethnography, 35(4), 373-395. http://dx.doi.org/10.1177/0891241605280449

Bernstein, M. (2002). 10 tips on writing the living Web. A List Apart: For People Who Make Websites, 149. Retrieved from http://www.alistapart.com/articles/writeliving

Burke, M. A. (2008). Double Consciousness. In R. Schaefer (Ed.), Encyclopedia of Race, Ethnicity and Society (pp. 412-414). Thousand Oaks, CA: Sage Publications, Inc. http://dx.doi.org/10.4135/9781412963879.n169

Collins, P. H. (2004). Black Sexual Politics: African Americans, Gender and the New Racism. New York, NY: Routledge. http://dx.doi.org/10.4324/9780203309506

Connelly, R., \& Ghodsee, K. (2011). The value of self-promotion. Inside higher education. Retrieved from https://www.insidehighered.com/advice/2011/07/18/essay on importance of self-promotion for young faculty members

Day, K. (2012). Unfinished Business: Black Women, the Black Church and the Struggle to Thrive in America. Maryknoll, NY: Orbis Books.

DuBois, W. E. B. (2008). The Souls of Black Folk. Rockville, MD: Arc Manor. Retrieved from http://www.gutenberg.org/files/408/408-h/408-h.htm

Goffman, E. (1959). The Presentation of Self in Everyday Life. New York: Doubleday.

Grant, J. (1982). Black Women and the Church. In G. T. Hull, P. B. Scott, \& B. Smith (Eds.), All the Women Are White, All the Blacks Are Men: But Some of Us are Brave (pp. 141-152). New York: The Feminist Press.

Gregory, S. (1999). Black women in the academy: The secrets to success and achievement. Lanham, MD: University Press of America.

Johnson-Bailey, J., \& Cervero, R. (2008). Different worlds and divergent paths: Academic careers defined by race and gender. Harvard Educational Review, 78(2), 311-332. http://dx.doi.org/10.17763/haer.78.2.n153n67044365117

Jones, E. E., \& Pittman, T. S. (1982). Toward a general theory of strategic self-presentation. In J. Suls (Ed.), Psychological perspectives on the self (pp. 231-262). Hillsdale, NJ: Erlbaum.

Kamau, C. (2009). Strategising impression management in corporations: Cultural knowledge as capital. In D. Harorimana (Ed.), Cultural implications of knowledge sharing, management and transfer: Identifying 
competitive advantage.

Kim, D., Twombly, S., \& Wolf-Wendel, L. (2012). International faculty in American universities: Experiences of academic life, productivity, and career mobility. In Y. J. Xu (Ed.), New Directions for Institutional Research (Vol. 155, pp. 27-46). San Francisco, Wiley, Inc. http://dx.doi.org/10.1002/ir.20020

Liff, S., \& Ward, K. (2001). Distorted views through the glass ceiling: The construction of women's understanding of promotion and senior management positions. Gender, Work and Organization, 8(1), 19-36. http://dx.doi.org/10.1111/1468-0432.00120

Manusov, V., \& Spitzberg, B. (2008). Attribution theory. In L. A. Baxter, \& D. O. Braithwaite (Eds.), Engaging theories in interpersonal communication: Multiple perspectives (pp. 37-49). Thousand Oaks, CA: Sage. http://dx.doi.org/10.4135/9781483329529.n3

Maryann, A. (2011). What's holdingus back? NAFE Magazine.

Mensch, B. S., Ibrahim, B. L., Lee, S. M., \& El-Gibaly, O. (2003). Socialization to gender roles and marriage among Egyptian adolescents. Studies in Family Planning, 34(1), 8-18. http://dx.doi.org/10.1111/j.1728-4465.2003.00008.x

Miller, L. G., Cooke, L. L., Tsang, J., \& Morgan, F. (1992). Should I brag? Nature and impact of positive and boastful disclosures for women and men. Human Communication Research, 18, 364-399. http://dx.doi.org/10.1111/j.1468-2958.1992.tb00557.x

Moss-Racusin, C. A., \& Rudman, L. A. (2010). Understanding Disruptions in Women's Ability to Self Promote: The backlash avoidance model. Psychology of Women Quarterly, 34, 186-202. http://dx.doi.org/10.1111/j.1471-6402.2010.01561.x

Nevin, J. A. (1991). Beyond pride and humility. The Behavior Analyst, 14, 35-36.

Ngunjiri, F., Hernandez, K., \& Chang, H. (2010). Living autoethnography: Connecting life and research. Journal of Research Practice, 6(1).

Pride. (n.d.). Retrieved June 30, 2015, from http://www.merriam-webster.com/dictionary/pride

Rudman, L. (1998). Self-Promotion as a risk factor for women: The costs and benefits of counterstereotypical impression management. Journal of Personality and Social Psychology, 74(3), 629-645. http://dx.doi.org/10.1037/0022-3514.74.3.629

Sahih Muslim. (1652). Hadith. Retrieved July 15, 2014 from http://sunnah.com/muslim/33/15

Sahih Muslim. (1733). Hadith. Retrieved July 15, 2014 from http://sunnah.com/muslim/33/17

Shambaugh, R. (2008). It's not a glass ceiling, It's a sticky floor. NY, New York: McGraw-Hill.

Strauss, A., \& Corbin, J. (1998). Basics of Qualitative Research-Techniques and Procedures for Developing Grounded Theory. London: Sage Publications.

The Economist. (2013). Promotion and self-promotion: The lamentable lack of female professors, 408(8851), 70.

World Development Indicators: Labor force structure. (2014). World Development Indicators. Washington, D.C.: World Bank.

\section{Copyrights}

Copyright for this article is retained by the author(s), with first publication rights granted to the journal.

This is an open-access article distributed under the terms and conditions of the Creative Commons Attribution license (http://creativecommons.org/licenses/by/3.0/). 